Article

\title{
Is There Any Difference in the Impact of Digital Transformation on the Quantity and Efficiency of Enterprise Technological Innovation? Taking China's Agricultural Listed Companies as an Example
}

\author{
Haihua Liu ${ }^{1}$, Peng Wang ${ }^{2}$ and Zejun $\mathrm{Li}^{2}{ }^{2 *}$ \\ 1 School of Business, Hunan Institute of Technology, Hengyang 421002, China; hhliulw@163.com \\ 2 College of Computer Science and Engineering, Hunan Institute of Technology, Hengyang 421002, China; \\ wang_ppeng@hnu.edu.cn \\ * Correspondence: lzjfox@hnit.edu.cn
}

check for updates

Citation: Liu, H.; Wang, P.; Li, Z. Is There Any Difference in the Impact of Digital Transformation on the Quantity and Efficiency of Enterprise Technological Innovation? Taking China's Agricultural Listed Companies as an Example. Sustainability 2021, 13, 12972. https://doi.org/10.3390/su132312972

Academic Editor: Fabrizio D'Ascenzo

Received: 19 October 2021

Accepted: 22 November 2021

Published: 23 November 2021

Publisher's Note: MDPI stays neutral with regard to jurisdictional claims in published maps and institutional affiliations.

Copyright: (c) 2021 by the authors. Licensee MDPI, Basel, Switzerland. This article is an open access article distributed under the terms and conditions of the Creative Commons Attribution (CC BY) license (https:/ / creativecommons.org/licenses/by/ $4.0 /)$.

\begin{abstract}
The effect of digital transformation on enterprise technological innovation is reflected in quantity and quality, which may show heterogeneity. In this regard, this paper uses the data of China's A-share agricultural listed companies from 2015 to 2020 to compare the differential impact of enterprise digital transformation from the perspective of quantity and quality of technological innovation. Firstly, the Tobit model is used to test whether there are differences in the impact of digital transformation on the quantity and quality of technological innovation of agricultural enterprises, and heterogeneity is tested according to the nature of enterprises. Secondly, this paper explores the reasons digital transformation has different effects on the quantity and quality of technological innovation through mechanism analysis. Finally, according to the threshold model, the conditions for digital transformation to promote the quantity and quality of technological innovation of agricultural enterprises are discussed. The empirical results show that, first, the digital transformation of agricultural enterprises only promotes the number of technological innovations, and there is heterogeneity in the nature of enterprises, but the innovation efficiency is not affected. Second, the period expense rate will lead to digital transformation, having different effects on the quantity and efficiency of technological innovation of agricultural enterprises. Third, the impact of digital transformation on the technological innovation efficiency of agricultural enterprises has a significant single threshold effect, and when the period expense rate is less than the threshold, the digital transformation has a significant role in promotion.
\end{abstract}

Keywords: digital transformation; differential impact; enterprise innovation; innovation quality; quantity of innovation

\section{Introduction and Literature Review \\ 1.1. Background}

For enterprises, digital transformation is a way to solve complex and uncertain problems and improve innovation ability and operation efficiency by using digital technology. Digital technology has strong flexibility and integration. Through this, enterprises can not only better grasp the needs of the market but also promote the iterative innovation of products and services [1,2]. From the internal point of view, digital transformation will lead to changes in the enterprise structure to a certain extent and promote the enterprise to adapt to the structure of the external environment. Digital transformation needs a more efficient and open organizational form as the carrier so that enterprises can produce new ways of value creation. Moreover, enterprises implementing digital transformation can use data to optimize transaction processes, reduce transaction costs and improve the transaction success rate, so as to make enterprises develop well [3]. From an external perspective, 
enterprises can provide customers with more accurate and extensive services through data. Enterprises can not only maintain good operation of the current market, but also have the opportunity to seek untapped business opportunities and promote enterprise innovation. Digital transformation provides enterprises with an all-round and multi-angle optimization process generated by digital technology. Enterprises can realize the optimization of market resource allocation, the improvement of innovation driving effect and the high-quality development of industry [4-6].

The quantity and quality of technological innovation are two indispensable dimensions to comprehensively measure the innovation output and technological competitiveness of enterprises, which reflect the core competitive advantage of enterprises, and they are two aspects of the same problem [7-10]. The quantity of technological innovation reflects the overall scale of technological innovation. As the premise and basis of the quality of technological innovation, the quality of technological innovation depends on the improvement of the quantity of technological innovation. The quality of technological innovation reflects the efficiency of technological innovation, which is measured not only by "quantity" but also by economic value. Taking China as an example, the problem of "high quantity and low quality" widely exists in the technological innovation of enterprises. For enterprises, low-quality innovation will be lower than high-quality innovation in R \& D cost, technical content and potential commercial value. If we only pursue growth in terms of the number of technological innovations and ignore the quality of technological innovation, we will not only waste R \& D investment but also increase sunk costs. Moreover, low-quality innovation can not only cause enterprises to obtain excess innovation profits, but also lead to the phenomena of "bad money expelling good money" and "patent thickets", hindering the improvement of the subsequent innovation level. Therefore, it is necessary to comprehensively measure enterprise technological innovation from the perspective of quantity and quality, guide enterprises to take into account the quantity and quality of technological innovation and more effectively improve the innovation level of enterprises [11-14].

Digital transformation originates from the interaction between technological innovation and operational needs of enterprises, and it is the core force to promote technological innovation of enterprises [15-18]. It can be used as an external motivation to promote enterprise technological innovation, which is an internal demand for enterprises to realize digital transformation. In the process of digital transformation, enterprises upgrade and transform the industry through digital technology to promote enterprises to carry out technological innovation more effectively, causing enterprises to change from the traditional innovation mode to the new innovation mode of digital-driven development. Digital transformation affects the technological innovation level of enterprises in the following five ways: (1) Digital transformation can reduce the cost of enterprise innovation [19]. (2) Digital transformation can break the boundaries of time and space [20]. (3) Enterprises determine the characteristics of new products through digital transformation [21]. (4) Digital transformation deepens the collaborative relationship between various departments of enterprises and provides support for innovation [22]. (5) Digital transformation can change the traditional business model of enterprises and accelerate the pace of innovation [23]. To sum up, the role of digital transformation in promoting enterprise technological innovation is very obvious. However, the current innovation still has the problem of "high quantity and low quality". The impact of digital transformation on the quantity and quality of enterprise technological innovation has become a research problem of great practical significance $[15,24]$.

\subsection{Literature Review}

Kuester et al. [25] and Nambisan, Lyytinen, Majchrzak and Song [26] mentioned that there is little literature on the impact of digital transformation on the quantity and quality of enterprise innovation. This paper summarizes from two aspects: Quantity and quality, in terms of the number of technological innovations. Scholars believe that digital transformation can provide enterprises with stronger capabilities in resource integration, in- 
formation acquisition, and data analysis so as to increase the number of innovations [27,28]. Through digital transformation, enterprises can carry out digital or intelligent upgrading and transformation of existing products so as to promote innovation output [29]. Digitization has strong permeability and compatibility, enabling enterprises to make timely changes in the digital transformation process according to the changes of market demand, and merge digital technology with existing products and services [30]. Moreover, digital transformation also gives enterprises repeatability and unlimited design flexibility in R \& $\mathrm{D}$ activities. With the help of digital technology, enterprises can achieve cost-free expansion. Enterprises can repair defects, improve performance, add new functions in the product life cycle, promote innovation iteration based on digital technology, and greatly improve their innovation capabilities [31,32]. By sorting out the above-mentioned literature, it can be seen that the influence of digital transformation on the number of technological innovations of enterprises has an obvious promoting effect. In terms of the quality of technological innovation, ACS [33] and others believe that digital transformation can not only improve technological innovation but also become a strategic means to transfer knowledge and technology. Bharadwa [23] and others believe that the digital transformation strategy will use digital resources to generate differentiated value. Specifically, digital transformation will promote the exchange of new ideas between manufacturing enterprises and their value chain partners, promoting manufacturing enterprises to further improve business processes and related products. This digital transformation will greatly improve the technological innovation efficiency of enterprises [1]. However, certain scholars questioned the impact of digital transformation on improving the quality of technological innovation [34-36]. They believe that digital transformation does not "improve the quality and efficiency" of enterprise innovation, but only increases the number of enterprise innovations. Hu [37] and others hold that it is easier for some companies to apply for a large number of repetitive and low-quality patents through digital transformation to obtain government subsidies or use them as a tool to hinder other competitors. Therefore, there is still no clear result for the impact of digital transformation on the quality of enterprise technological innovation.

In summary, most relevant studies only focus on the quantity or quality of technological innovation, so there is still room for research on both the quantity and the quality of enterprise innovation simultaneously, which can more comprehensively reflect the impact of digital transformation on enterprise technological innovation. In this regard, this paper uses the data of China's A-share agricultural listed companies from 2015 to 2020 to explore whether there are differences in the impact of digital transformation on the quantity and quality of enterprise technological innovation, so as to enrich the research topics in this field. The marginal contribution of this paper is mainly reflected in four aspects. Firstly, this paper analyzes the impact of digital transformation from the two dimensions of enterprise technological innovation (i.e., quantity and quality), distinguishes the differential impact on the two dimensions and adds to the content of existing literature. Secondly, based on the differences in enterprise nature, this paper discusses the types of enterprises in which digital transformation can effectively promote technological innovation. Thirdly, through empirical analysis, this paper reveals the internal mechanism of digital transformation affecting the quantity and quality of enterprise technological innovation, and further discusses the reasons for these effects. Fourthly, through the internal mechanism research, this paper studies how digital transformation can effectively improve the quality of enterprise technological innovation, explores the conditions for digital transformation to promote the quality of innovation and prevents the recurrence of the problem of "high quantity and low quality".

The rest of this paper is arranged as follows: The second part presents the research design, including analyzing the basic theory and putting forward research hypotheses, setting models and describing variables; the third part details the empirical analysis, including benchmark regression and a heterogeneity test; the fourth part contains further discussion, including exploring the reasons for the different effects of digital transformation and the conditions for digital transformation to significantly improve the quality of technological 
innovation of agricultural enterprises; the fifth part presents the conclusion and policy recommendations.

\section{Study Design}

\subsection{Theoretical Analysis and Research Hypothesis}

The impact of digital transformation on technological innovation is a stimulus as a whole. Digital transformation has expanded the scope of enterprise technological innovation, making it easier to stimulate new technologies or inventions, thereby increasing the number of innovations [38]. Not only that, but digital transformation may also reduce the cost of innovation and realize economies of scope through digital technology and information sharing, thereby reducing the cost of innovation for enterprises and increasing the number of innovations. Digital transformation can also effectively reduce the innovation risk of enterprises. Enterprise technological innovation is usually accompanied by various risks. The success rate of single-project research and development is often low. However, through digital transformation, enterprises can use digital technology to assist innovation activities, thereby reducing the risk of technological innovation and increasing the number of innovations. However, the impact of digital transformation on the quality of technological innovation may not be significant. First, digital transformation may squeeze out $R \& D$ investment in technological innovation, which leads to insufficient investment in existing technologies, and the efficiency of technological innovation will be reduced, hindering the technological innovation of enterprises. Second, the degree of digitization is not enough to affect the efficiency of technological innovation of enterprises. Digital transformation is in the development stage for enterprises and cannot provide sufficient support for technological innovation [39-41]. Based on the above analysis, this paper proposes the following hypothesis:

Hypothesis 1 (H1). The impact of digital transformation on the technological innovation of agricultural enterprises is different in both quantity and quality.

As far as the enterprise nature is concerned, the impact of digital transformation between state-owned and non-state-owned enterprises on enterprise technological innovation may be different [42]. Non-state-owned enterprises face strong financial exclusion and discrimination in the financial market under the traditional financial system, which deepens information asymmetry between non-state-owned enterprises and traditional financial institutions. With the help of digital transformation, it is easier for non-stateowned enterprises to obtain financial support. In addition, the systems and mechanisms of non-state-owned enterprises are more flexible and can be adjusted quickly with the development of digital transformation, thus making the innovation incentive effect of digital transformation more obvious [43-47]. However, due to the weak R\&D capabilities of most companies and the lack of common technology platforms in the industry, many companies mainly rely on the purchase of foreign advanced equipment and the introduction of production capabilities to achieve digital transformation. The result is that Chinese companies lack core technologies and independent innovation capabilities, resulting in a lower quality of enterprise technological innovation [48]. Therefore, this paper believes that the current level of digital transformation is not enough to affect the quality of enterprise technological innovation. Based on the above analysis, this paper proposes the following hypothesis:

Hypothesis 2 (H2). The impact of digital transformation on the quantity of technological innovation of different types of agricultural enterprises is heterogeneous, but there is no heterogeneity in the quality of technological innovation of agricultural enterprises.

If there is inconsistency in the impact of digital transformation on the quantity and quality of enterprise technological innovation, this paper explores the reasons for its occurrence through mechanism analysis. This paper believes that in the process of digital 
transformation, companies are affected by certain factors, causing them to face the problem of "high quantity, low quality". By drawing lessons from previous studies [49], this paper believes that the factors may be related to the company's period expenses. The amount of expenditure during a period reflects the operating conditions of the enterprise and will have a certain impact on the technological innovation of the enterprise. If the proportion of expenditure during the period increases in the process of enterprise technological innovation, enterprises will not invest more resources to improve the level of technological innovation from the perspective of profitability. This means enterprises have a large number of innovative products, but they still lack market competitiveness. Therefore, this paper believes that the period cost may be used as an intermediary variable to affect the process of digitalization on the quantity and quality of enterprise technological innovation. Based on the above analysis, the following hypothesis is proposed:

Hypothesis 3 (H3). There is an intermediary effect in the process of digital transformation affecting the quantity of technological innovation of agricultural enterprises, while the process of affecting the quality of technological innovation of agricultural enterprises does not exist.

If the period expenditure is the reason digitization does not play a significant role in the quality of enterprise technological innovation, this paper discusses the conditions for digital transformation to effectively improve the quality of enterprise technological innovation. Since digital transformation can significantly increase the number of technological innovations of enterprises through the expenditure of period expenses, is there a suitable range of period expense ratios so that digital transformation has the same impact on the quality of technological innovation? Hansen [50] used the threshold model to test whether the financial constraints of 565 US companies affect investment decisions. The result is a dual-threshold model, and based on the empirical results, the appropriate range of financial constraints affecting investment choices is analyzed. Therefore, this paper also analyzes the threshold effect for the above-mentioned problems, discusses the range of the proportion of expenses during the period, and finds the conditions for effectively improving the quality of technological innovation [51,52]. Based on the above analysis, the following hypothesis is put forward:

Hypothesis $4 \mathbf{( H 4 ) . ~ T h e r e ~ i s ~ a ~ t h r e s h o l d ~ e f f e c t ~ i n ~ t h e ~ p r o c e s s ~ o f ~ d i g i t a l ~ t r a n s f o r m a t i o n ~ a f f e c t i n g ~ t h e ~}$ quality of agricultural enterprise technological innovation.

\subsection{Model Design}

In order to explore whether there are differences in the impact of digital transformation on the quantity and quality of technological innovation in agricultural enterprises, this paper constructs a Tobit model and a panel linear regression model for empirical testing. Restricted types of data are suitable for the Tobit model, especially truncated data such as the number of patent applications granted (the number of patent applications granted $>0$ ) and the technological innovation efficiency measured by DEA $(0<$ technical innovation efficiency < 1). Therefore, this paper chooses the Tobit model as the benchmark model for regression analysis. The Tobit model is set as follows:

$$
\begin{gathered}
\text { InPatent }_{i t}=\alpha_{0}+\alpha_{1} \times \text { Dig }_{i t}+\sum_{j=2}^{6} \alpha_{j} \times \text { Control }_{i t}+\varepsilon_{i t} \\
\text { InPatent }_{i t}=\left\{\begin{array}{c}
\text { InPatent }_{i t}, \\
0, \text { lnPatent }_{i t}>0 \\
\text { Efficiency }_{i t}=\alpha_{0}+\alpha_{1} \times \text { Dig }_{i t}+\sum_{j=2}^{6} \alpha_{j} \times \text { Control }_{i t}+\varepsilon_{i t}
\end{array}\right.
\end{gathered}
$$




$$
\text { Efficiency }_{i t}=\left\{\begin{array}{cl}
\text { Efficiency }_{i t}, & 0<\text { Efficiency }_{i t}<1 \\
\mathbf{0} & , \text { Efficiency }_{i t} \leq 0 \\
\mathbf{1} & , \text { Efficiency }_{i t} \geq 1
\end{array}\right.
$$

As shown in Model 1 and Model 2, InPatent $_{i t}$ represents the quantity of agricultural enterprise technological innovation, Efficiency ${ }_{i t}$ represents the quality of agricultural enterprise technological innovation, $\boldsymbol{D i g}_{i t}$ represents the degree of digital transformation of the enterprise, Control $_{i t}$ represents the control variable, $\varepsilon_{i t}$ represents the residual item and $\alpha_{0}-\alpha_{6}$ are the coefficients of the variable. $t$ represents the year, $i$ represents the enterprise, and the model controls the individual effect and the time effect in empirical analysis.

If digital transformation has different effects on the quantity and quality of technological innovation in agricultural enterprises, in order to explore the reasons for this situation, this paper discusses them through mechanism analysis, that is, constructing an intermediary effect model for empirical analysis. By referring to the research of Baron et al., the following mediation effect model is established:

$$
\begin{gathered}
\text { Med }_{i t}=\beta_{0}+\beta_{1} \times \operatorname{Dig}_{i t}+\sum_{j=2}^{6} \beta_{j} \times \text { Control }_{i t}+\varepsilon_{i t} \\
\text { InPatent }_{i t}=\beta_{0}^{\prime}+\beta_{1}^{\prime} \times \operatorname{Dig}_{i t}+\beta_{2}^{\prime} \times \operatorname{Med}_{i t}+\sum_{j=3}^{7} \beta_{j}^{\prime} \times \text { Control }_{i t}+\varepsilon_{i t} \\
\text { Efficiency }_{i t}=\beta_{0}^{\prime}+\beta_{1}^{\prime} \times \operatorname{Dig}_{i t}+\beta_{2}^{\prime} \times \operatorname{Med}_{i t}+\sum_{j=3}^{7} \beta_{j}^{\prime} \times \text { Control }_{i t}+\varepsilon_{i t}
\end{gathered}
$$

In the above model, $\mathbf{M e d}_{i t}$ represents the intermediate variable, and the other variables are consistent with those in Models (1) and (2).

If the current digital transformation has an insignificant impact on the quality of agricultural enterprise technological innovation, the main reason is that the intermediary effect is not significant. This paper selects the intermediary variable as the threshold variable and constructs a threshold model for empirical analysis, in order to explore the conditions for digital transformation to significantly improve the quality of technological innovation in agricultural enterprises. The setting of the threshold model is as follows:

$$
\text { Efficiency }_{i t}=\phi_{0}+\phi_{1} \times \operatorname{Dig}_{i t} \mathrm{I}\left(q_{i t} \leq \gamma\right)+\phi_{1}^{\prime} \times \operatorname{Dig}_{i t} \mathrm{I}\left(q_{i t}>\gamma\right)+\sum_{j=2}^{6} \phi_{j} \times \text { Control }_{i t}+\varepsilon_{i t}
$$

In Model (6), $q_{i t}$ represents the threshold variable and $\gamma$ represents the threshold value, and the remaining variables are consistent with those in Models (1) and (2).

\subsection{Variable Description and Data Sources}

\subsubsection{Explained Variables}

This paper uses the number of patent applications granted by agricultural enterprises (lnPatent) to represent the number of technological innovations of enterprises and uses DEA to measure the efficiency of technological innovation of enterprises to measure the quality of technological innovation of agricultural enterprises. Because DEA measures a wide range of indicators, it can more accurately measure the technological innovation capabilities of agricultural enterprises. Taking into account the characteristics of technological innovation of agricultural enterprises and the availability of data, this paper selects the following indicators to measure the efficiency of technological innovation of agricultural enterprises. The investment indicators are the amount of R\&D investment and the number of R\&D personnel, which are used to reflect the investment of human resources and capital in the enterprise's technological innovation. The output indicators are the number of patent applications granted, main business income and profitability. The number of patent applications granted can reflect the technological innovation level of 
agricultural enterprises. The main business income determines the subsequent investment in technological innovation. Profitability will have an impact on technological innovation. Therefore, the above indicators are selected for calculation in this paper, and the specific instructions are shown in Table 1.

Table 1. Measurement indicators of technological innovation efficiency.

\begin{tabular}{|c|c|c|}
\hline Primary Indicators & Secondary Indicators & Indicator Description \\
\hline \multirow[t]{2}{*}{ Input indicators } & R \& D input & $\begin{array}{l}\text { Investment of R \& D funds in the } \\
\text { annual report of listed companies }\end{array}$ \\
\hline & Number of R \& D personnel & $\begin{array}{c}\text { Investment of } \mathrm{R} \& \mathrm{D} \text { personnel in } \\
\text { the annual report of listed } \\
\text { companies }\end{array}$ \\
\hline \multirow[t]{3}{*}{ Output indicators } & patents granted & $\begin{array}{l}\text { Number of authorized invention } \\
\text { patents of listed companies }\end{array}$ \\
\hline & Main business income & $\begin{array}{c}\text { Main business income of listed } \\
\text { companies }\end{array}$ \\
\hline & Profitability & Tobin Q value of listed companies \\
\hline
\end{tabular}

\subsubsection{Explanatory Variables}

Drawing lessons from Ghosh's literature [53], this paper collects data from companies' annual reports, uses the proportion of digital-related intangible assets to measure the degree of digital transformation of the company and studies the impact of digital transformation on the quantity and quality of technological innovation of the company. The digital-related intangible asset, which exists in the form of electronic data, is owned or controlled by enterprises in daily sale and productional processes [54]. The items include, for example, Finance and logistics software, Finance software, Management software, Computer and Computer software, Application software, Patents and related patent projects and so on.

\subsubsection{Control Variables}

Based on previous studies, this paper selects the enterprise debt ratio, equity concentration, proportion of fixed assets, degree of financing constraints and enterprise scale as control variables. The greater the debt ratio of enterprises, the more reluctant enterprises are to support technological innovation activities. The stronger the degree of ownership concentration, the more vulnerable the enterprise's technological innovation ability is to the behavior of major shareholders. The proportion of fixed assets will affect the investment level of enterprises in technological innovation. The external financing environment limits the technological innovation activities of enterprises to a certain extent, and innovative enterprises are more vulnerable to financing constraints. Moreover, this paper uses the SA index to measure the degree of financing constraints of enterprises. The calculation formula of the SA index is $-0.737 \times$ Size $+0.043 \times$ Size $^{2}-0.04 \times$ Age, where Size represents the size of the enterprise and Age represents the age of the enterprise. Technological innovation investment is also subject to enterprise scale. Therefore, this paper selects the above indicators as control variables.

\subsubsection{Intermediary Variables and Threshold Variables}

When exploring whether there are intermediary effects and threshold effects in the process of digital transformation affecting the quantity and quality of technological innovation of enterprises, this paper combs through previous scholars' research and finds that the period expense rate can be used as an appropriate intermediary variable and threshold variable. The period expense rate refers to the rate at which the costs incurred in the daily activities of the enterprise cannot be included in the specific accounting object but should be included in the expenses incurred in the current period of profit and loss. The period expenses of an enterprise frequently occur in business activities and are highly prone to waste or loss, which will not only affect the profit of the enterprise but may also affect 
the survival and development of the enterprise. In the process of digital transformation, enterprises use digital technology to alleviate corporate information asymmetry, reduce information search, bargaining and contracting and other expenses in the process of market transactions, and reduce unnecessary purchases, marketing and logistics through the integration of technology and business forms. Therefore, this paper believes that the period expense rate can be used as a suitable intermediary variable and threshold variable to enable digital transformation to impact the technological innovation of enterprises through it. The calculation formula of the period expense ratio is: (sales expense + management expense + financial expense)/operating income. The above data are all from the annual report of the listed companies.

The research object of this paper is China's A-share listed agricultural, forestry, animal husbandry and fishery companies from 2015 to 2020. After considering the availability and validity of the data, this paper excludes $\mathrm{ST}$, *ST, PT and companies with severely missing data, and finally selects 27 listed agricultural, forestry, animal husbandry and fishery companies as the research objects. The data come from the CSMAR Guotaian database. In order to avoid errors in the research results caused by the different units of the variables, this paper conducts logarithmic processing on the number of patents granted by enterprises and the size of enterprises and supplements the missing data by means of average interpolation. The specific description of the above variables is shown in Table 2, and the descriptive statistics of the variables are shown in Table 3.

Table 2. Variable selection and description.

\begin{tabular}{|c|c|c|c|}
\hline Variable Type & Variable Name & Variable Symbol & Variable Explanation \\
\hline \multirow[t]{2}{*}{ Explained variable } & $\begin{array}{l}\text { Number of enterprise } \\
\text { technological innovation }\end{array}$ & lnPatent & $\begin{array}{c}\text { Log (number of patent applications } \\
\text { granted }+1)\end{array}$ \\
\hline & $\begin{array}{l}\text { Enterprise technological } \\
\text { innovation quality }\end{array}$ & Efficiency & Calculation using DEA model \\
\hline Explanatory variable & Degree of digital transformation & Dig & $\begin{array}{c}\text { Proportion of intangible assets related } \\
\text { to digitalization }\end{array}$ \\
\hline \multirow[t]{4}{*}{ Control variable } & Enterprise debt ratio & Lev & Asset liability ratio of enterprises \\
\hline & Ownership concentration & Only1 & $\begin{array}{c}\text { Shareholding ratio of the largest } \\
\text { shareholder }\end{array}$ \\
\hline & $\begin{array}{l}\text { Proportion of fixed assets } \\
\text { Degree of financing constraints }\end{array}$ & $\begin{array}{l}\text { Ppe } \\
\text { Sa }\end{array}$ & $\begin{array}{l}\text { Proportion of fixed assets in total assets } \\
\text { SA index }\end{array}$ \\
\hline & Enterprise scale & Size & $\begin{array}{c}\text { Total assets of the enterprise at the end } \\
\text { of the year }\end{array}$ \\
\hline $\begin{array}{l}\text { Intermediary/threshold } \\
\text { variables }\end{array}$ & Period expense rate & Ass & $\begin{array}{c}\text { Sales expenses }+ \text { administrative } \\
\text { expenses }+ \text { financial } \\
\text { expenses/operating revenue }\end{array}$ \\
\hline
\end{tabular}

Table 3. Descriptive Statistics.

\begin{tabular}{ccccccc}
\hline VarName & Obs & Mean & SD & Min & Median & Max \\
\hline lnPatent & 162 & 0.438 & 0.954 & 0.000 & 0.000 & 3.829 \\
Efficiency & 162 & 0.285 & 0.395 & 0.000 & 0.079 & 1.000 \\
Dig & 162 & 0.065 & 0.128 & 0.000 & 0.026 & 0.781 \\
Lev & 162 & 0.448 & 0.191 & 0.059 & 0.421 & 0.980 \\
Only1 & 162 & 32.382 & 15.610 & 4.080 & 30.950 & 70.000 \\
Ppe & 162 & 0.269 & 0.139 & 0.048 & 0.244 & 0.643 \\
Sa & 162 & 4.236 & 1.263 & 1.931 & 3.936 & 8.459 \\
Lnsize & 162 & 22.269 & 1.033 & 20.320 & 22.089 & 25.535 \\
Ass & 162 & 0.572 & 0.376 & 0.086 & 0.466 & 1.827 \\
\hline
\end{tabular}




\section{Empirical Analysis}

\subsection{Benchmark Regression}

Due to the truncation characteristics of the quantity and efficiency of technological innovation data of agricultural enterprises, this paper uses Stata16.0 to empirically test model (1) and model (2) and discusses the impact of digital transformation on the quantity and quality of enterprise technological innovation. Not only that, but we also calculate the marginal effect that belongs to the censored regression models' marginal effect. In addition, we use the two-stage, least-square (2SLS) and Generalized Method of Moments (GMM) models as robustness tests to verify the empirical results. In the robustness test, we choose the instrumental variables as the lagged first order of Dig. On the one hand, the lagged first order of digital transformation (1.Dig) can avoid endogenous problems when exploring the influence of digital transformation on the quantity and efficiency of enterprise technological innovation; on the other hand, it can draw a better comparison with the results from the Tobit model. The empirical results are shown in Table 4 and the results of the robustness test are shown in Table 5.

Table 4. Benchmark regression.

\begin{tabular}{|c|c|c|c|c|}
\hline & \multicolumn{4}{|c|}{ Tobit } \\
\hline & lnPatent (1) & Marginal Effect (2) & Efficiency (3) & Marginal Effect (4) \\
\hline \multirow[t]{2}{*}{ Dig } & $39.283^{* *}$ & $0.818 *$ & -1.714 & -0.119 \\
\hline & $(2.333)$ & $(1.751)$ & $(-1.066)$ & $(-0.731)$ \\
\hline \multirow[t]{2}{*}{ Lev } & $-6.130^{* * *}$ & $-0.818^{* *}$ & $-0.594^{* * *}$ & -0.090 \\
\hline & $(-2.639)$ & $(-1.992)$ & $(-2.727)$ & $(-0.352)$ \\
\hline \multirow[t]{2}{*}{ Only1 } & -0.036 & $-0.012 * * *$ & $-0.013^{* * *}$ & 0.010 \\
\hline & $(-1.048)$ & $(-3.119)$ & $(-2.748)$ & $(1.479)$ \\
\hline \multirow[t]{2}{*}{ Ppe } & $8.522 * *$ & 0.234 & 0.329 & 0.679 \\
\hline & $(2.347)$ & $(0.501)$ & $(0.779)$ & $(1.490)$ \\
\hline \multirow[t]{2}{*}{ Sa } & 0.403 & -0.028 & -0.080 & 1.053 * \\
\hline & $(0.242)$ & $(-0.081)$ & $(-0.343)$ & $(1.850)$ \\
\hline \multirow[t]{2}{*}{ Lnsize } & -0.776 & 0.194 & -0.108 & $-1.500 * *$ \\
\hline & $(-0.357)$ & $(0.670)$ & $(-0.357)$ & $(-2.110)$ \\
\hline Time effect & YES & YES & YES & YES \\
\hline Individual effect & YES & YES & YES & YES \\
\hline \multirow[t]{2}{*}{ _Cons } & 16.273 & & 3.641 & \\
\hline & $(0.385)$ & & $(0.622)$ & \\
\hline $\mathrm{N}$ & 186 & 186 & 186 & 186 \\
\hline
\end{tabular}

Table 5. The robustness test.

\begin{tabular}{|c|c|c|c|c|}
\hline & 2SLS (1) & 2SLS (2) & GMM (1) & GMM (2) \\
\hline & lnPatent & Efficiency & lnPatent & Efficiency \\
\hline \multirow[t]{2}{*}{ Dig } & $3.312 *$ & -2.308 & $3.740 * * *$ & -0.629 \\
\hline & $(1.679)$ & $(-0.443)$ & $(2.643)$ & $(-1.548)$ \\
\hline \multirow[t]{2}{*}{ Lev } & -0.671 * & -0.181 & $1.793^{* * *}$ & -0.029 \\
\hline & $(-1.836)$ & $(-0.199)$ & $(3.834)$ & $(-0.119)$ \\
\hline \multirow[t]{2}{*}{ Only1 } & $-0.017^{* * *}$ & -0.017 & -0.006 & $0.018^{* * *}$ \\
\hline & $(-2.935)$ & $(-0.369)$ & $(-0.670)$ & $(2.923)$ \\
\hline \multirow[t]{2}{*}{ Ppe } & 0.621 & 1.334 & $-4.338^{* * *}$ & $1.543^{* * *}$ \\
\hline & $(1.216)$ & $(0.876)$ & $(-5.464)$ & $(4.347)$ \\
\hline \multirow[t]{2}{*}{ Sa } & 0.554 & 0.571 & $3.994 * * *$ & -0.593 * \\
\hline & $(0.937)$ & $(0.274)$ & $(6.925)$ & $(-1.757)$ \\
\hline \multirow[t]{2}{*}{ Lnsize } & -0.535 & -0.814 & $-5.473 * * *$ & 0.622 \\
\hline & $(-0.731)$ & $(-0.277)$ & $(-7.107)$ & $(1.498)$ \\
\hline Time effect & YES & YES & YES & YES \\
\hline Individual effect & YES & YES & & \\
\hline L.lnPatent & & & $\begin{array}{c}0.438^{* * *} \\
(20.944)\end{array}$ & \\
\hline \multirow[t]{2}{*}{ L.efficiency } & & & & -0.033 \\
\hline & & & & $(-0.730)$ \\
\hline \multirow[t]{2}{*}{ _cons } & 11.070 & 17.483 & $105.685^{* * *}$ & -12.009 \\
\hline & $(0.791)$ & $(0.311)$ & (7.106) & $(-1.519)$ \\
\hline $\mathrm{N}$ & 135 & 135 & 108 & 108 \\
\hline
\end{tabular}

Note: ${ }^{*}, * *$ and ${ }^{* * *}$ represent passing the significance test of $10 \%, 5 \%$ and $1 \%$. 
The empirical results in Table 4 show that digital transformation can effectively increase the number of technological innovations of agricultural enterprises, but it cannot improve its technological innovation efficiency. This paper sets up a Tobit model for empirical analysis. By comparing columns (1) and (3) in Table 4, it can be seen that the influence coefficient of digital transformation on the number of technological innovations of agricultural enterprises is 39.283 , which is significant at the $5 \%$ significance level. The influence coefficient of digital transformation on the efficiency of technological innovation of agricultural enterprises is -1.714 , but it is not significant. In order to ensure the accuracy of the experimental results, this paper conducts an empirical analysis on the 2SLS and GMM models. By comparing column (1) and column (2) in Table 5 it can be seen that the coefficient of influence of digital transformation on the number of technological innovations of agricultural enterprises is 3.312, which is significant at a significance level of $10 \%$. The influence coefficient of digital transformation on the technological innovation efficiency of agricultural enterprises is -2.308 , but the influence coefficient is not significant. Furthermore, the GMM model has the same effect in Table 5. This shows that digital transformation has a significant role in promoting the number of technological innovations of agricultural enterprises and cannot impact the efficiency of technological innovation of agricultural enterprises, and the empirical results are robust. Therefore, Hypothesis 1 is verified.

The reason for this situation may be that the quantity and quality of technological innovation in agricultural enterprises are inconsistent with the level of demand for digital transformation. From a quantitative perspective, digital transformation increases the number of technological innovations by improving corporate liquidity, financing costs and operating income. Due to the shortcomings of China's traditional financial system and the limitations of enterprises, China's traditional finance will not significantly promote the technological innovation of agricultural enterprises. On the one hand, China's traditional financial system is dominated by banks, and there are problems of single financing methods, w lack of financing channels, and conservative risk assessments. China's traditional financial system cannot provide adequate support, which is very detrimental to the development of technological innovation in agricultural enterprises with large capital needs, long maturities and high uncertainties. On the other hand, certain agricultural enterprises have few mortgage assets and low credit, which is seriously inconsistent with the banks' credit preference. The bank will worry that the risk is too high, so it will refuse to provide sufficient financial support to agricultural enterprises. The emergence of digital transformation provides effective solutions for technological innovation of agricultural enterprises. It not only solves the problems of single financing methods and lack of financing channels for enterprises, but also alleviates the problem of information asymmetry between enterprises and financial institutions. This has led to a substantial increase in the number of technological innovations with the help of digital transformation. Shahrokhi [55] believes that digital transformation can enable companies to reduce costs through digital finance, expand the scope of financial services and provide more opportunities for companies' innovation patents. Fuster [56] believes that the traditional financial system has cumbersome procedures and low efficiency in financing. The digital transformation of enterprises reduces the information costs and transaction costs of investors through the use of digital technology while reducing corporate credit risk premiums and corporate financing costs. Digital transformation enriches the types of financial services that enterprises receive, makes it easier for enterprises to obtain financing channels and increases the opportunities for enterprise technological innovation. From a quality point of view, the influence of digital transformation on the efficiency of technological innovation is insufficient. Technological innovation efficiency is an indicator that measures technological innovation from many aspects. The current digital transformation is still in the development stage. In addition to expanding financing methods and alleviating information asymmetry to help enterprises improve the level of innovation, it cannot have a major impact on other aspects of technological innovation. Digital transformation has not tapped into the diversity of 
its functions, and the way to support technological innovation is not singular, and as a result, digital transformation is not the main factor affecting the quality of technological innovation of agricultural enterprises. Nieto et al. [57] believe that digital transformation does not necessarily promote innovation efficiency.

\subsection{Heterogeneity Analysis of the Role of Digital Transformation}

According to the characteristics of agricultural enterprises, this paper classifies agricultural enterprises (state-owned enterprises and non-state-owned enterprises) according to the nature and further studies the differential impact of digital transformation of different enterprises on technological innovation from the two aspects of quantity and quality. The empirical results are shown in Table 6.

Table 6. Results of the heterogeneity test.

\begin{tabular}{|c|c|c|c|c|}
\hline & $\begin{array}{l}\text { State-Owned } \\
\text { Enterprise (1) }\end{array}$ & $\begin{array}{l}\text { State-Owned } \\
\text { Enterprise (2) }\end{array}$ & $\begin{array}{c}\text { Non-State- } \\
\text { Owned } \\
\text { Enterprises (3) }\end{array}$ & $\begin{array}{c}\text { Non-State- } \\
\text { Owned } \\
\text { Enterprises (4) }\end{array}$ \\
\hline & lnPatent & Efficiency & lnPatent & Efficiency \\
\hline \multirow[t]{2}{*}{ Dig } & -2.845 & -3.264 & 11.695 * & 0.051 \\
\hline & $(-1.350)$ & $(-1.570)$ & $(1.900)$ & $(0.035)$ \\
\hline \multirow[t]{2}{*}{ Lev } & -0.392 & 0.088 & -1.116 & $-0.520 *$ \\
\hline & $(-0.358)$ & $(0.173)$ & $(-1.281)$ & $(-1.906)$ \\
\hline \multirow[t]{2}{*}{ Only1 } & -0.010 & 0.008 & 0.003 & 0.001 \\
\hline & $(-0.731)$ & $(0.524)$ & $(0.102)$ & (0.143) \\
\hline \multirow[t]{2}{*}{ Ppe } & $-3.190 *$ & 0.939 & $-4.087^{*}$ & 0.023 \\
\hline & $(-1.877)$ & $(0.708)$ & $(-1.940)$ & $(0.035)$ \\
\hline \multirow[t]{2}{*}{ Sa } & $3.580 * * *$ & $-1.570^{* *}$ & $2.185^{* *}$ & $-0.726^{*}$ \\
\hline & $(2.911)$ & $(-2.505)$ & $(2.444)$ & $(-1.883)$ \\
\hline \multirow[t]{2}{*}{ Lnsize } & $-4.169 * * *$ & 1.535 * & $-3.116^{* * *}$ & 0.743 \\
\hline & $(-2.707)$ & (1.922) & $(-2.965)$ & (1.594) \\
\hline Individual effect & Yes & Yes & Yes & Yes \\
\hline \multirow[t]{2}{*}{ _Cons } & $81.529 * * *$ & $-29.063 *$ & $61.245^{* * *}$ & -12.611 \\
\hline & $(2.688)$ & $(-1.847)$ & $(3.040)$ & $(-1.412)$ \\
\hline $\mathrm{N}$ & 72 & 72 & 114 & 114 \\
\hline
\end{tabular}

Note: ${ }^{*}{ }^{* *}$ and ${ }^{* * *}$ represent passing the significance test of $10 \%, 5 \%$ and $1 \%$.

The results in Table 6 show that in terms of the nature of the enterprise, the effect of digital transformation on the number of technological innovations of agricultural enterprises displays obvious differences, but the effect on the efficiency of technological innovation of agricultural enterprises is not differentiated. By comparing columns (1) and (3), it can be seen that in state-owned enterprises, the impact of digital transformation on the number of technological innovations of agricultural enterprises is not significant. In non-state-owned enterprises, the influence coefficient of digital transformation on the number of technological innovations of agricultural enterprises is 11.695, which is significant at a significance level of $10 \%$. By comparing columns (2) and (4), we can see that digital transformation has no significant impact on the number of technological innovations in agricultural enterprises, regardless of whether in state-owned or non-state-owned enterprises. This shows that the heterogeneous effect of digital transformation on the quantity of technological innovation of agricultural enterprises is manifested in the nature of the enterprise, while the impact on the efficiency of technological innovation of agricultural enterprises is not different in terms of the nature of the enterprise. Therefore, Hypothesis 2 is verified.

In regard to quantity, the reason for the heterogeneity of the impact of digital transformation on technological innovation may be that non-state-owned enterprises can receive the same financial services as state-owned enterprises from banks and other financial institutions in the process of digital transformation. Since non-state-owned enterprises are not controlled by the government, they are subject to strong financing constraints and 
less financial support in the traditional financial market, which ultimately leads to the deepening of information asymmetry between traditional financial institutions and nonstate-owned enterprises. In the process of digital transformation of enterprises, financial institutions can use digital technology to quickly assess the credit level and corporate value of non-state-owned enterprises and increase the possibility of financing. Moreover, the systems and mechanisms of non-state-owned enterprises are more flexible. Non-state-owned enterprises can quickly adjust innovation financing decisions according to the degree of digital transformation, optimize the allocation of innovation resources and ultimately enable digital transformation to effectively increase the number of technological innovations. For state-owned enterprises, there are capital, scientific research, scale and policy advantages. The current role of digital transformation is to expand financing channels and alleviate information asymmetry, and these problems do not exist for state-owned enterprises. As a result, digital transformation cannot significantly affect the technological innovation of state-owned enterprises and cannot significantly increase the number of patent applications of state-owned enterprises. Huang et al. [43] took the innovation level of enterprises as the research object and analyzed the agglomeration characteristics based on panel data of 23 industrial sectors in China from 2001 to 2013. They divided enterprises into the following types: State-owned enterprises, private enterprises and foreign-funded enterprises. The research results show that although state-owned enterprises have far more $R \& D$ investment and $R \& D$ personnel than the other three types of enterprises, the innovation level of state-owned enterprises is lower than that of private enterprises. This shows that non-state-owned enterprises have strong technological innovation capabilities, so the digital transformation is more suitable for non-state-owned enterprises. In terms of quality, there is no heterogeneity in the impact of digital transformation on enterprise technological innovation. This shows that whether it is a state-owned enterprise or a non-state-owned enterprise, the degree of digital transformation does not have an impact on the efficiency of technological innovation. It may be because there are too many factors restricting technological innovation in non-state-owned enterprises, and the current degree of digital transformation of enterprises cannot effectively improve the efficiency of technological innovation. For state-owned enterprises, digital transformation is not a factor that significantly affects technological innovation. Innovation quality includes multiple levels of innovation indicators, and the degree of digital transformation is not enough to have a significant impact on multi-angle corporate innovation.

\section{Further Discussion}

4.1. Exploration of the Reasons Why Digital Transformation Has Different Effects on the Quantity and Quality of Technological Innovation in Agricultural Enterprises

In order to study the reasons for the differences in the impact of digital transformation on the quantity and quality of agricultural enterprise technological innovation, this paper establishes the mediating effect models (3), (4), and (5) and analyzes the internal mechanism for discussion. The empirical results are shown in Table 7.

The results in Table 7 show that digital transformation has different effects on the quantity and efficiency of agricultural enterprise technological innovation, which may be caused by the period expense ratio. In column (1), the coefficient of influence of digital transformation on the period expense ratio is 5.221 , which is significant at the $1 \%$ significance level. Through empirical regression of model (4) and model (5), the empirical results of column (2) and column (3) are obtained. As shown in column (2), under the influence of the period expense ratio, the coefficient of influence of digital transformation on the number of technological innovations of agricultural enterprises is 6.266, which is significant at a significance level of 5\%; the period expense ratio affects the number of technological innovations of agricultural enterprises; the influence coefficient is 0.378 , and it is significant at the $5 \%$ significance level. As shown in column (3), under the influence of the period expense rate, the impact of digital transformation on the technological innovation efficiency of agricultural enterprises is not significant, and the effect of the period expense rate on the technological innovation efficiency of agricultural enterprises 
is also insignificant. This shows that digital transformation can increase the number of technological innovations of agricultural enterprises through the period expense rate but cannot improve the efficiency of agricultural enterprises' technological innovation. The period expense rate may be the reason that the two are affected differently. Therefore, Hypothesis 3 is verified.

Table 7. Test results of mediation effect.

\begin{tabular}{cccc}
\hline & & Soble $=\mathbf{1 . 9 7 4} \mathbf{*}^{*}$ & Soble $=\mathbf{0 . 3 4 1}$ \\
\hline Variable & Ass (1) & lnPatent (2) & Efficiency (3) \\
\hline Dig & $5.221^{* * *}$ & $6.266^{* *}$ & -0.842 \\
& $(4.280)$ & $(1.980)$ & $(-0.600)$ \\
Ass & & $0.378^{* *}$ & 0.0653 \\
& & $(2.010)$ & $(0.790)$ \\
Lev & -0.175 & $-0.691^{*}$ & -0.146 \\
Only1 & $(-1.230)$ & $(-1.970)$ & $(-0.940)$ \\
& -0.00307 & $-0.0146^{* * *}$ & $0.00464^{* *}$ \\
Ppe & $(-1.650)$ & $(-3.170)$ & $(2.280)$ \\
& $0.403^{* *}$ & -0.439 & -0.215 \\
Sa & $(2.260)$ & $(-0.990)$ & $(-1.100)$ \\
& 0.112 & 0.235 & $-0.343^{* * *}$ \\
Lnsize & $(1.020)$ & $(0.860)$ & $(-2.840)$ \\
& -0.0803 & -0.193 & $0.331^{* *}$ \\
Time effect & $(-0.590)$ & $(-0.580)$ & $(2.240)$ \\
Individual effect & YES & YES & YES \\
Cons & YES & YES & $-5.668^{* *}$ \\
& 1.913 & 4.380 & $(-2.030)$ \\
$\mathrm{N}$ & $(0.740)$ & $(0.690)$ & 186 \\
\hline
\end{tabular}

Note: ${ }^{*},{ }^{* *}$ and ${ }^{* * *}$ represent passing the significance test of $10 \%, 5 \%$ and $1 \%$.

The reason for this situation may be that the quantity and quality of technological innovation are inconsistent with the requirements of the period expense rate in the process of digital transformation. In the process of digital transformation, the period expenses of enterprises show an upward trend. This is because the initial stage of digital transformation will produce frequent waste or loss. In business activities, companies do not correctly grasp the process of digital transformation, which increases the company's period expense ratio. Regarding the number of technological innovations, the increase in the period expense rate will reduce the promotion of digitalization to the number of innovations, but the change in the period expense rate is still within the scope that digital transformation can increase the number of technological innovations. Moreover, in order to maintain a favorable competitive position in the market, companies are willing to apply for a large number of innovative patents at the expense of high cost and high consumption. In this process, the increase in business expenses during the period is very significant. However, for companies that only pursue the amount of innovation, this method can relatively enable the company to maintain its competitive advantage. For the quality of technological innovation, when the period expenses are relatively large, enterprises are prone to waste resources and increase costs in the process of technological innovation. Due to the broader coverage of technological innovation efficiency, digital transformation cannot solve the negative effects caused by expenses during the period. As a result, digital transformation cannot significantly improve the technological innovation efficiency of agricultural enterprises. At this time, the change in the period expense rate has exceeded the scope of the digital transformation to promote the enterprise's technological innovation efficiency. If the enterprise cannot limit the increase in the expense ratio during the period, the impact of digital transformation on its technological innovation quality will not be able to reach its needs. 


\subsection{Exploration of the Conditions for Digital Transformation to Effectively Improve the} Technological Innovation Efficiency of Agricultural Enterprises

Through the above research, this paper has drawn conclusions on the reasons for the different effects of digital transformation on the quantity and quality of enterprise technological innovation. Due to the relatively high proportion of period expenses, the quality of technological innovation of enterprises has been greatly hindered. In this regard, this paper explores the conditions for digital transformation to effectively improve the efficiency of technological innovation, that is, to explore the size of the period expense rate when digital transformation effectively improves the efficiency of technological innovation in agricultural enterprises. This paper draws on previous studies and establishes model (6) to conduct an empirical analysis on the threshold effect. This paper uses the period expense rate as the threshold variable, sets the number of self-samplings to 300 and tests the threshold value of the model in turn. The empirical results are shown in Tables 8 and 9.

Table 8. Threshold test.

\begin{tabular}{cccc}
\hline & F Statistics & $p$-Value & Threshold Value \\
\hline TH-1 & 12.91 & 0.087 & $0.086 *$ \\
TH-2 & 3.13 & 0.687 & 0.5632 \\
TH-3 & 11.05 & 0.233 & 0.5606 \\
\hline Note: $^{*},{ }^{* *}$ and & *** represent passing the significance test of $10 \%, 5 \%$ and $1 \%$.
\end{tabular}

Table 9. Threshold regression results.

\begin{tabular}{cc}
\hline & Efficiency \\
\hline $\operatorname{Dig}($ ass $\leq 0.086)$ & $13.715^{*}$ \\
$\operatorname{Dig}(0.086<$ ass $<0.5632)$ & $(1.687)$ \\
& -0.579 \\
$\operatorname{Dig}($ ass $\geq 0.5632)$ & $(-1.580)$ \\
& -0.019 \\
Control & $(-0.074)$ \\
Time effect & YES \\
Cons & YES \\
$\mathrm{N}$ & -8.858 \\
\end{tabular}

Note: ${ }^{*}{ }^{* *}$ and ${ }^{* * *}$ represent passing the significance test of $10 \%, 5 \%$ and $1 \%$.

It can be seen from Table 8 that when the period expense rate is used as a threshold variable, the impact of digital transformation on innovation efficiency has a single threshold effect. The threshold value is 0.086 , and it is significant at the $10 \%$ significance level.

The results in Table 9 show that when the period expense ratio is small, digital transformation can significantly improve the efficiency of technological innovation of agricultural enterprises. When the period expense ratio is less than or equal to 0.086 , the coefficient of influence of digital transformation on the efficiency of agricultural enterprise technological innovation is 13.715 and is significant at a significance level of $10 \%$. When the period expense ratio is greater than 0.086 , the impact of digital transformation on the efficiency of technological innovation of agricultural enterprises is not significant. This shows that when the period expense ratio is 0.086 , there is a turning point in digital transformation, and there is a threshold effect. That is, when the period expense rate is low, digital transformation can improve the efficiency of technological innovation of agricultural enterprises; when the period expense rate exceeds the optimal level, the effect of digital transformation will be reduced.

This may be because the expenditure of period expenses plays an important role in enterprise technological innovation As the sales expenses, management expenses and 
financial expenses may be used irregularly and calculated inaccurately in the process of enterprise operation, this will affect the income and profit of the enterprise. For technological innovation, companies dare not devote most of their resources to the innovation process with unclear results, because technological innovation cannot help agricultural companies obtain short-term profits, and there are large uncertainties in the stages of research, testing and sales. Therefore, in order to achieve the purpose of reducing costs and improving benefits, enterprises must pay attention to and strengthen the benefit management of period costs. Particularly for the creation of intangible assets, such as new product development, market expansion, after-sales service and the use of information technology, standardized management can bring long-term economic benefits to the enterprise. It can also accelerate the capital turnover of enterprises and increase capital utilization, so that the company can effectively innovate in the process of resource investment. This will increase the innovation competitiveness of enterprises, improve their technological innovation efficiency and maintain their competitive advantages.

\section{Conclusions}

Based on the data of China's A-share agricultural listed companies from 2015 to 2020, this paper focuses on comparing the differential impact of digital transformation on the quantity and quality of enterprise technological innovation on the premise of controlling a variety of other factors that may affect technological innovation. Compared with theoretical analysis, this paper uses the results of empirical analysis to study how to efficiently support the technological innovation of agricultural enterprises, which is more targeted. In particular, it conducts in-depth research on the conditions and reasons for digital transformation to promote enterprise technological innovation from the perspective of quantity and quality. This paper measures technological innovation from the perspective of quantity and quality and explores the differences between the two aspects of the impact of digital transformation on enterprise technological innovation and discusses whether different types of enterprises also have such differences. On this basis, this paper uses mechanism analysis and threshold effect analysis to study the reasons for the different effects of digital transformation and the conditions for promoting technological innovation. Based on this, this paper draws the following conclusions:

(1) The effects of digital transformation on the quantity and efficiency of technological innovation of agricultural enterprises are different. As the current digital transformation is in the developing stage, the impact on technological innovation has not reached the ideal level. Moreover, in order to ensure continuous competitive advantage in the market, companies are willing to conduct patent applications and other activities at the expense of high costs and a large number of resources. This has caused the problem of "high quantity and low quality" among enterprises to become more serious, and digital transformation cannot be effectively suppressed. Companies are also relying on digital transformation to optimize the innovation environment and further increase the number of innovations, but the attention to quality is obviously insufficient.

(2) In terms of the nature of enterprises, the effect of digital transformation on the number of innovations of agricultural enterprises shows obvious differences, but the effect on the efficiency of technological innovation of agricultural enterprises is not differentiated. In the process of digital transformation, non-state-owned enterprises reduce financing constraints and ease information asymmetry, which provides quite favorable conditions for the number of innovations. Relatively speaking, the conditions of state-owned enterprises have reached the optimal level, and digital transformation cannot provide further assistance in reducing financing constraints. Therefore, the impact on the number of innovations is not significant. However, as far as innovation quality is concerned, the problem of a low degree of digital transformation still exists. It will still not have a significant impact on the innovation efficiency of the two types of enterprises. 
(3) The period expense ratio is the reason that the digital transformation has a different effect on the quantity and efficiency of technological innovation of agricultural enterprises. Expenses during the period reflect the current operating conditions of the enterprise. If the proportion of expenditures during the period is relatively large, there will be a waste of resources and increased costs, which will have an adverse impact on the innovation of the enterprise. Since some companies are pursuing an increase in the number of innovations, they are willing to sacrifice a higher cost in exchange for the number of innovations that tend to rise. However, the measurement of the efficiency of technological innovation will be adversely affected by the increase in expenses during the period, and digital transformation cannot currently solve this problem. Therefore, the period expense ratio is the reason that causes the digital transformation to have different effects on the quantity and quality of technological innovation.

(4) The impact of digital transformation on the technological innovation efficiency of agricultural enterprises has a significant single-threshold effect, and when the period expense rate is small, digital transformation has a significant promotion effect. This shows that digital transformation can effectively promote the development of enterprise technological innovation quality under suitable conditions. The period expense ratio is a significant influencing factor in the process of digital transformation affecting the quality of technological innovation. When the period expense ratio is small, the company's resource waste and cost increase are alleviated, and the promotion of digital transformation is also significantly improved.

Based on the above research conclusions, this paper obtains the following policy enlightenment. First, the state has issued effective policies to prohibit enterprises from excessively pursuing "high quantity and low quality" of innovation, reasonably "improve quality and efficiency" of enterprise innovation and accelerate the process of enterprise digital transformation. Taking China's agricultural listed companies as an example, this paper determines from the empirical results that digital transformation has a significant role in promoting the number of enterprise technological innovations, but it has no significant effect on the quality of enterprise technological innovation [58]. This paper believes that, on the one hand, the degree of digital transformation of enterprises is not high, and on the other hand, the lack of emphasis on innovation quality by enterprises leads to the fact that innovation quality is not affected by it. Therefore, this paper believes that the incentive effect of digital transformation on enterprise innovation can be better brought into play through national policies [59]. Second, non-state-owned enterprises should focus on improving the degree of digital transformation. Such enterprises have abundant financing channels and provide continuous economic support for their technological innovation. Not only that, but non-state-owned enterprises are flexible, and they can better adapt to the process of digital transformation driven by the goal of profit maximization, making the promotion of digital transformation more obvious. State-owned enterprises develop other projects that can support technological innovation, and do not need to invest more resources and costs in reaching the optimal conditions. Third, enterprises should limit the expenditure of period expenses. The high cost during the period will have a certain impact on the development and innovation of the enterprise. The empirical results show that the excessively high period cost is the factor that causes the digital transformation to have an insignificant impact on the quality of enterprise technological innovation. Moreover, it will also have a certain degree of impact on the number of technological innovations in enterprises $[60,61]$. Therefore, this paper believes that when companies continue to improve the degree of digital transformation and reduce the waste of resources and other adverse effects, the period expense ratio will reach the appropriate level for the company. This can not only reflect the high-quality operation level of the enterprise, but also effectively improve the quantity and quality of technological innovation. Fourth, in the process of innovation and development, non-state-owned enterprises that are small and middle size should actively use digital technology and digital platforms to reconstruct 
and integrate the original innovation process and mode. Due to the agriculture enterprises having a heterogeneous effect on the nature of enterprises, in this process, we should pay more attention to improving organizational dynamic ability through training development and process reengineering. Enterprises also promote the reorganization of traditional innovation resources in the process of enterprise digital transformation and dispose of innovation path dependence and strategic stickiness. For those enterprises with large strategic changes, we should pay more attention to cultivating organizational dynamic ability and improving strategic flexibility, so they can better adapt to the complex and dynamic innovation environment in the era of the digital economy. This paper believes that there is still room for research on the quantity and quality of digital transformation and innovation. First, this paper explores the differential impact of digital transformation on the quantity and quality of innovation based on the data of listed agricultural companies in China, but this only represents the situation of listed agricultural companies. For companies in other sectors, such as manufacturing, the role of digital transformation may be different. It is more convincing to extend this research method to other types of companies for comparison. Second, there may be more than one reason for the differential impact of digital transformation. This paper draws on previous studies and confirms the existence of one cause through empirical tests, but there may still be other factors. Therefore, more in-depth research can also be carried out in the future.

Author Contributions: H.L. contributed to all aspects of this work; Z.L. conducted the data analysis and wrote the main manuscript text. P.W. reviewed the manuscript. All authors have read and agreed to the published version of the manuscript.

Funding: This work was supported by the National Nature Science Foundation of China (grant number 61672223) and the Project of Hunan Institute of Technology (grant number HQ20004).

Data Availability Statement: The data presented in this study are available on request from the author.

Conflicts of Interest: The authors declare no conflict of interest.

\section{References}

1. Nambisan, S.; Wright, M.; Feldman, M. The Digital Transformation of Innovation and Entrepreneurship: Progress, Challenges and Key Themes. Res. Policy 2019, 48, 103773. [CrossRef]

2. Xu, M.; Albitar, K.; Li, Z. Does corporate financialization affect EVA? Early evidence from China. Green Financ. $2020,2,392-408$. [CrossRef]

3. Li, L.; Su, F.; Zhang, W.; Mao, J.-Y. Digital transformation by SME entrepreneurs: A capability perspective. Inf. Syst. J. 2017, 28, 1129-1157. [CrossRef]

4. $\quad$ Birkel, H.S.; Veile, J.W.; Müller, J.M.; Hartmann, E.; Voigt, K.-I. Development of a Risk Framework for Industry 4.0 in the Context of Sustainability for Established Manufacturers. Sustainability 2019, 11, 384. [CrossRef]

5. Moeuf, A.; Pellerin, R.; Lamouri, S.; Tamayo, S.; Barbaray, R. The industrial management of SMEs in the era of Industry 4.0. Int. J. Prod. Res. 2017, 56, 1118-1136. [CrossRef]

6. $\mathrm{Hu}, \mathrm{J} . ;$ Huang, Q.; Chen, X. Environmental Regulation, Innovation Quality and Firms' Competitivity?Quasi-Natural Experiment Based on China's Carbon Emissions Trading Pilot. Econ. Res.-Ekon. Istraz. 2020, 33, 3307-3333. [CrossRef]

7. Hu, J.; Pan, X.; Huang, Q. Quantity or Quality? The Impacts of Environmental Regulation on Firms' Innovation-Quasi-Natural Experiment Based on China's Carbon Emissions Trading Pilot. Technol. Forecast. Soc. Chang. 2020, 158. [CrossRef]

8. Dang, J.; Motohashi, K. Patent statistics: A good indicator for innovation in China? Patent subsidy program impacts on patent quality. China Econ. Rev. 2015, 35, 137-155. [CrossRef]

9. Pan, X.; Cheng, W.; Gao, Y.; Balezentis, T.; Shen, Z. Is Environmental Regulation Effective in Promoting the Quantity and Quality of Green Innovation? Environ. Sci. Pollut. Res. 2021, 28, 6232-6241. [CrossRef]

10. Lin, J.; Wu, H.-M.; Wu, H. Could Government Lead the Way? Evaluation of China's Patent Subsidy Policy on Patent Quality * China Econ. Rev. 2021, 69, 101663. [CrossRef]

11. Jia, N.; Huang, K.G.-L.; Zhang, C.M. Public Governance, Corporate Governance, and Firm Innovation: An Examination of State-Owned Enterprises. Acad. Manag. J. 2019, 62, 220-247. [CrossRef]

12. Lv, X.; Qi, Y.; Dong, W. Dynamics of Environmental Policy and Firm Innovation: Asymmetric Effects in Canada's Oil and Gas Industries. Sci. Total Environ. 2020, 712, 136371. [CrossRef] [PubMed]

13. Yang, C.; Li, T.; Albitar, K. Does Energy Efficiency Affect Ambient Pm2.5? The Moderating Role of Energy Investment. Front. Environ. Sci. 2021, 9, 707751. [CrossRef] 
14. Hong, M.; Drakeford, B.; Zhang, K. The impact of mandatory CSR disclosure on green innovation: Evidence from China. Green Financ. 2020, 2, 302-322. [CrossRef]

15. Mueller, J.M.; Buliga, O.; Voigt, K.-I. The Role of Absorptive Capacity and Innovation Strategy in the Design of Industry 4.0 Business Models-a Comparison between Smes and Large Enterprises. Eur. Manag. J. 2021, 39, 333-343. [CrossRef]

16. Li, Z.; Chen, L.; Dong, H. What Are Bitcoin Market Reactions to Its-Related Events? Int. Rev. Econ. Financ. 2021, 73, 1-10. [CrossRef]

17. Ante, L. Bitcoin transactions, information asymmetry and trading volume. Quant. Financ. Econ. 2020, 4, 365-381. [CrossRef]

18. Pabuçcu, H.; Ongan, S.; Ongan, A. Forecasting the movements of Bitcoin prices: An application of machine learning algorithms. Quant. Financ. Econ. 2020, 4, 679-692. [CrossRef]

19. Shao, B.; Lin, W.T. Assessing Output Performance of Information Technology Service Industries: Productivity, Innovation and Catch-Up. Int. J. Prod. Econ. 2016, 172, 43-53. [CrossRef]

20. Hess, T.; Matt, C.; Benlian, A.; Wiesböck, F. Options for Formulating a Digital Transformation Strategy. MIS Q. Exec. 2016, 15, 123-139.

21. Hamidi, A.; Safabakhsh, M. The Impact of Information Technology on E. Marketing. In Proceedings of the 1st World Conference on Information Technology (WCIT), Bahcesehir University, Istanbul, Turkey, 6-10 October 2010.

22. Vial, G. Understanding digital transformation: A review and a research agenda. J. Strateg. Inf. Syst. 2019, 28, 118-144. [CrossRef]

23. Bharadwaj, A.; Sawy, O.A.; Pavlou, P.; Venkatraman, N. Digital Business Strategy: Toward a Next Generation of Insights. MIS Q. 2013, 37, 471-482. [CrossRef]

24. Zhou, J.; Li, P.; Zhou, Y.; Wang, B.; Zang, J.; Meng, L. Toward New-Generation Intelligent Manufacturing. Engineering 2018, 4, 11-20. [CrossRef]

25. Kuester, S.; Konya-Baumbach, E.; Schuhmacher, M.C. Get the show on the road: Go-to-market strategies for e-innovations of start-ups. J. Bus. Res. 2018, 83, 65-81. [CrossRef]

26. Nambisan, S.; Kalle, L.; Ann, M.; Michael, S. Digital Innovation Management: Reinventing Innovation Management Research in a Digital World. MIS Q. 2017, 41, 223-238. [CrossRef]

27. Li, J.; Saide, S.; Ismail, M.N.; Indrajit, R.E. Exploring IT/IS proactive and knowledge transfer on enterprise digital business transformation (EDBT): A technology-knowledge perspective. J. Enterp. Inf. Manag. 2021. Available online: https://www. emerald.com/insight/content/doi/10.1108/JEIM-08-2020-0344/full/html (accessed on 15 September 2021).

28. Sia, S.K.; Weill, P.; Zhang, N. Designing a Future-Ready Enterprise: The Digital Transformation of DBS Bank. Calif. Manag. Rev. 2021, 63, 35-57. [CrossRef]

29. Moretti, N.; Ellul, C.; Cecconi, F.R.; Papapesios, N.; Dejaco, M.C. GeoBIM for built environment condition assessment supporting asset management decision making. Autom. Constr. 2021, 130, 103859. [CrossRef]

30. Paritala, P.K.; Manchikatla, S.; Yarlagadda, P.K.D.V. Digital Manufacturing-Applications Past, Current, and Future Trends. In Proceedings of the 13th Global Congress on Manufacturing and Management (GCMM), Zhengzhou University, Zhengzhou, China, 28-30 November 2016.

31. Manesh, M.F.; Pellegrini, M.M.; Marzi, G.; Dabic, M. Knowledge Management in the Fourth Industrial Revolution: Mapping the Literature and Scoping Future Avenues. IEEE Trans. Eng. Manag. 2020, 68, 289-300. [CrossRef]

32. Pizzi, S.; Venturelli, A.; Variale, M.; Macario, G.P. Assessing the impacts of digital transformation on internal auditing: A bibliometric analysis. Technol. Soc. 2021, 67, 101738. [CrossRef]

33. Acs, Z.J.; Braunerhjelm, P.; Audretsch, D.B.; Carlsson, B. The knowledge spillover theory of entrepreneurship. Small Bus. Econ. 2008, 32, 15-30. [CrossRef]

34. Barrett, M.I.; Elizabeth, D.; Jaideep, P.; Stephen, L.V. Service Innovation in the Digital Age: Key Contributions and Future Directions. MIS Q. 2015, 39, 135-154. [CrossRef]

35. Greenstein, S.; Lerner, J.; Stern, S. Digitization, Innovation, and Copyright: What Is the Agenda? Strateg. Organ. 2013, 11, 110-121. [CrossRef]

36. Yoo, Y.; Boland, R.J., Jr.; Lyytinen, K.; Majchrzak, A. Organizing for Innovation in the Digitized World. Organ. Sci. 2012, 23, 1398-1408. [CrossRef]

37. Hu, A.G.Z.; Zhang, P.; Zhao, L. China as Number One? Evidence from China's Most Recent Patenting Surge. J. Dev. Econ. 2017, 124, 107-119. [CrossRef]

38. Warner, K.; Wäger, M. Building dynamic capabilities for digital transformation: An ongoing process of strategic renewal. Long Range Plan. 2018, 52, 326-349. [CrossRef]

39. Ferreira, J.J.; Fernandes, C.I.; Ferreira, F.A. To be or not to be digital, that is the question: Firm innovation and performance. J. Bus. Res. 2018, 101, 583-590. [CrossRef]

40. Li, J.-P.O.; Liu, H.; Ting, D.S.J.; Jeon, S.; Chan, R.V.P.; Kim, J.E.; Sim, D.A.; Thomas, P.B.M.; Lin, H.; Chen, Y.; et al. Digital technology, tele-medicine and artificial intelligence in ophthalmology: A global perspective. Prog. Retin. Eye Res. 2021, 82, 100900. [CrossRef]

41. Demirtaş, Y.E.; Keçeci, N.F. The efficiency of private pension companies using dynamic data envelopment analysis. Quant. Financ. Econ. 2020, 4, 204-219. [CrossRef]

42. Yin, Z.; Liu, L.; Wang, H.; Wen, F. Study on the ownership balance and the efficiency of mixed ownership enterprises from the perspective of heterogeneous shareholders. PLoS ONE 2018, 13, e0194433. [CrossRef] 
43. Huang, S.; Bai, Y.; Tan, Q. How Does the Concentration of Determinants Affect Industrial Innovation Performance?-An Empirical Analysis of 23 Chinese Industrial Sectors. PLOS ONE 2017, 12, e0169473. [CrossRef] [PubMed]

44. Li, Z.; Wang, Y.; Huang, Z. Risk Connectedness Heterogeneity in the Cryptocurrency Markets. Front. Phys. 2020, 8. [CrossRef]

45. Li, T.; Liao, G. The Heterogeneous Impact of Financial Development on Green Total Factor Productivity. Front. Energy Res. 2020, 8. [CrossRef]

46. Matei, I. Is financial development good for economic growth? Empirical insights from emerging European countries. Quant. Financ. Econ. 2020, 4, 653-678. [CrossRef]

47. Iwedi, M.; Anderson, O.E.; Barisua, P.S.; Zaagha, S.A. Enterprise risk management practice and shareholders value: Evidence from selected quoted firms in Nigeria. Green Financ. 2020, 2, 197-211. [CrossRef]

48. Zhang, T.; Shi, Z.-Z.; Shi, Y.-R.; Chen, N.-J. Enterprise digital transformation and production efficiency: Mechanism analysis and empirical research. 2021. [CrossRef]

49. Chen, X.; Lu, H.; Sougiannis, T. The Agency Problem, Corporate Governance, and the Asymmetrical Behavior of Selling, General, and Administrative Costs. Contemp. Account. Res. 2011, 29, 252-282. [CrossRef]

50. Hansen, B.E. Threshold Effects in Non-Dynamic Panels: Estimation, Testing, and Inference. J. Econom. 1999, 93, 345-368. [CrossRef]

51. Li, Z.; Zou, F.; Tan, Y.; Zhu, J. Does Financial Excess Support Land Urbanization—An Empirical Study of Cities in China. Land 2021, 10, 635. [CrossRef]

52. Li, T.; Ma, J.; Mo, B. Does the Land Market Have an Impact on Green Total Factor Productivity? A Case Study on China. Land 2021, 10, 595. [CrossRef]

53. Ghosh, K.; Khuntia, J.; Chawla, S.; Deng, X. Media Reinforcement for Psychological Empowerment in Chronic Disease Management. Commun. Assoc. Inf. Syst. 2014, 34, 419-438. [CrossRef]

54. Verhoef, P.C.; Broekhuizen, T.; Bart, Y.; Bhattacharya, A.; Dong, J.Q.; Fabian, N.; Haenlein, M. Digital transformation: A multidisciplinary reflection and research agenda. J. Bus. Res. 2019, 122, 889-901. [CrossRef]

55. Shahrokhi, M. E-finance: Status, innovations, resources and future challenges. Manag. Financ. 2008, 34, 365-398. [CrossRef]

56. Fuster, A.; Plosser, M.; Schnabl, P.; Vickery, J. The Role of Technology in Mortgage Lending. Rev. Financ. Stud. 2019, 32, 1854-1899. [CrossRef]

57. Nieto, M.J.; Santamaria, L. The importance of diverse collaborative networks for the novelty of product innovation. Technovation 2007, 27, 367-377. [CrossRef]

58. Wimelius, H.; Mathiassen, L.; Holmström, J.; Keil, M. A paradoxical perspective on technology renewal in digital transformation. Inf. Syst. J. 2020, 31, 198-225. [CrossRef]

59. Hron, M.; Obwegeser, N.; Müller, S.D. Innovation drift: The influence of digital artefacts on organizing for innovation. Innovation 2021. [CrossRef]

60. Shirish, A.; Batuekueno, L. Technology renewal, user resistance, user adoption: Status quo bias theory revisited. J. Organ. Chang. Manag. 2021, 34, 874-893. [CrossRef]

61. Hongo, D.O.; Li, F.; Ssali, M.W.; Nyaranga, M.S.; Musamba, Z.M.; Lusaka, B.N. Inflation, unemployment and subjective wellbeing: Nonlinear and asymmetric influences of economic growth. Natl. Account. Rev. 2020, 2, 1-25. [CrossRef] 